\title{
Histopathological changes in the swimbladder wall of the European eel Anguilla anguilla due to infections with Anguillicola crassus
}

\author{
Jürgen Würtz ${ }^{1}$, Horst Taraschewski ${ }^{2, *}$ \\ ${ }^{1}$ Institut für Zoologie und Limnologie, Universität Innsbruck, Technikerstraße 25, 6020 Innsbruck, Austria \\ ${ }^{2}$ Zoologisches Institut/Ökologie, Universität Karlsruhe, Kaiserstraße 12, 76128 Karlsruhe, Germany
}

\begin{abstract}
The histopathological changes in swimbladders of European eels naturally and experimentally infected with Anguillicola crassus were studied using transmission and scanning electron microscopy. During the course of probably several infections swimbladders undergo characteristic changes. In addition to the thickening of the entire swimbladder wall, and to the folded internal surface of this organ, inflammation, migration of white blood cells, fibrosis and changes in the epithelial cells are frequently seen. Epithelial cells tend to proliferate heavily and form hyperplastic tissues; these processes are accompanied by changes in the internal structure of the cells. The normally cubic cells become spherical or columnar and form folds facing the lumen of the swimbladder. As a consequence, most of these cells lose contact with the blood vessels and show no strict polarity. In heavily affected swimbladders the basal labyrinth of the epithelial cells is reduced, i.e. becomes shorter and less densely packed. The lamina propria shows severe fibrosis with infiltration of white blood cells. Larvae of $A$. crassus, inhabiting the wall of the swimbladder, were found to be surrounded by cell debris, but this local necrosis does not affect the entire swimbladder in its overall structure. These histological findings can partly explain changes in the gas composition in eels infected with $A$. crassus.
\end{abstract}

KEY WORDS: Anguillicola crassus · Eel A Anguilla anguilla $\cdot$ Swimbladder · Histology · Pathology . Ultrastructure

\section{INTRODUCTION}

After the introduction of the eel pathogenic nematode Anguillicola crassus from East Asia to Europe in the early 1980s (Neumann 1985) many reports have dealt with the prevalence and spread of this parasite, first in Europe and Africa and in very recent years also in the USA (Canestri-Trotti 1987, Taraschewski et al. 1987, Dupont \& Petter 1988, Køie 1988, Moravec \& Taraschewski 1988, Belpaire et al. 1989, Dekker \& Van Willigen 1989, Koops \& Hartmann 1989, Fontaine et al. 1990, Kennedy \& Fitch 1990, Möller et al. 1991, Székely et al. 1991, Höglund et al. 1992, Moravec 1992, Mo \& Steien 1994, Fries et al. 1996, Schabuss et al. 1997, Würtz et al. 1998). Another focus of interest has

-Corresponding author. E-mail: dc20@rz.uni-karlsruhe.de been the biology and development of $A$. crassus since virtually nothing was known about this nematode before it was introduced to Europe (De Charleroy et al. 1990, Bonneau et al. 1991, Moravec et al. 1993, Thomas \& Ollevier 1993, Hartmann 1994, Moravec \& Konecny 1994, Moravec et al. 1994, Nagasawa et al. 1994). In Japan it is known that this parasite does not cause serious pathological damage to the indigenous Japanese eel Anguilla japonica (Egusa 1979, Kim et al. 1989, Nagasawa et al. 1994). On the other hand, early studies of Egusa (1979) previously revealed changes in the swimbladder of infected European eels Anguilla anguilla imported to culture ponds in Japan. Since the introduction of $A$. crassus to Europe, conspicuous histopathological changes in the swimbladder of infected European eels have been confirmed (Molnár et al. 1993, 1995, Hartmann 1994, Molnár 1994, Haenen 1995). Inflammation, dilation of the blood vessels, for- 
mation of granuloma, and thickening of the entire swimbladder wall have been observed in these light microscopical studies. So far, however, pathological changes in the swimbladder of eels induced by A. crassus have not been studied by means of an electron microscope. The aim of this paper was to document tissue alterations on the ultrastructural level. We also tried to find histological evidence for the changes in the gas composition of infected swimbladders as described by Würtz et al. (1996).

\section{MATERIAL AND METHODS}

About 100 eels, caught at several sample sites in the rivers Rhine and Naab, Germany (Würtz et al. 1997), were used for this histopathological study. Additionally, experimentally infected eels, which were kept in aquaria for 5 mo p.i. (post-infection), were used for this investigation. The mean intensities of these experimentally infected eels were 3.4 to 13.8 (Wurtz et al. 1996). The eels were transported to the laboratory alive, killed by decapitation and subsequently dissected. Samples of the swimbladder wall were cut into small pieces and immediately placed in a solution of $5 \%$ glutaraldehyde buffered in $0.1 \mathrm{M}$ cacodylate (pH 7.4) and fixed overnight at $4^{\circ} \mathrm{C}$. For transmission electron microscopy (TEM) the tissue was washed in $0.1 \mathrm{M}$ cacodylate buffer for $20 \mathrm{~min}$, post-fixed in cold $2 \%$ $\mathrm{OsO}_{4}$ for $2 \mathrm{~h}$, dehydrated through graded acetone series and embedded in Spurr low viscosity resin (Spurr 1969). Ultrathin sections were cut with a Ultracut UCT (Reichert, Austria), double stained with uranyl acetate and lead citrate and examined in a EM900 and EM902 (Zeiss, Oberkochen). For scanning electron microscopy (SEM) the samples were dehydrated after fixation using graded acetone series, critical-point dried with liquid $\mathrm{CO}_{2}$, sputtered with goid and examined with a Stereoscan S4 (Cambridge Instruments).

\section{RESULTS}

The swimbladder is a derivative of the fore intestine and its wall shows the same stratification as does the intestine. Therefore, the terminology suggested by Fänge (1953) will be used in this article

\section{General histology and scanning electron microscopy}

The swimbladder wall of Anguilla anguilla consists of 4 distinct layers (Fig. 1). The innermost layer facing the lumen is the mucosa, with a simple cuboidal epithelium of gas gland cells and a thin, richly vascularized lamina propria. The mucosa is followed by a muscle layer, the muscularis mucosae. The third layer, the submucosa, is characterized by a loose network of connective tissue. A serosa constitutes the outermost layer of the swimbladder wall. This histological arrangement is typical of the whole secretory part, which forms the largest section of the swimbladder. The resorbing part of the swimbladder (the pneumatic duct), which is morphologically different from the secretory part (Dorn 1961), is not considered here.

As described earlier (Würtz et al. 1998), about 30\% of all feral eels examined showed macroscopically visible alterations in the swimbladder wall due to infections with Anguillicola crassus. Almost $16 \%$ of uninfected eels also revealed alterations in the swimbladder wall. Minor alterations were apparent such as inflammations and dilated blood vessels. Changes in the swimbladder walls of experimentally infected eels were confined to those inflammatory reactions. Heavily affected swimbladders were characterised by macroscopically visible clouding and thickening of

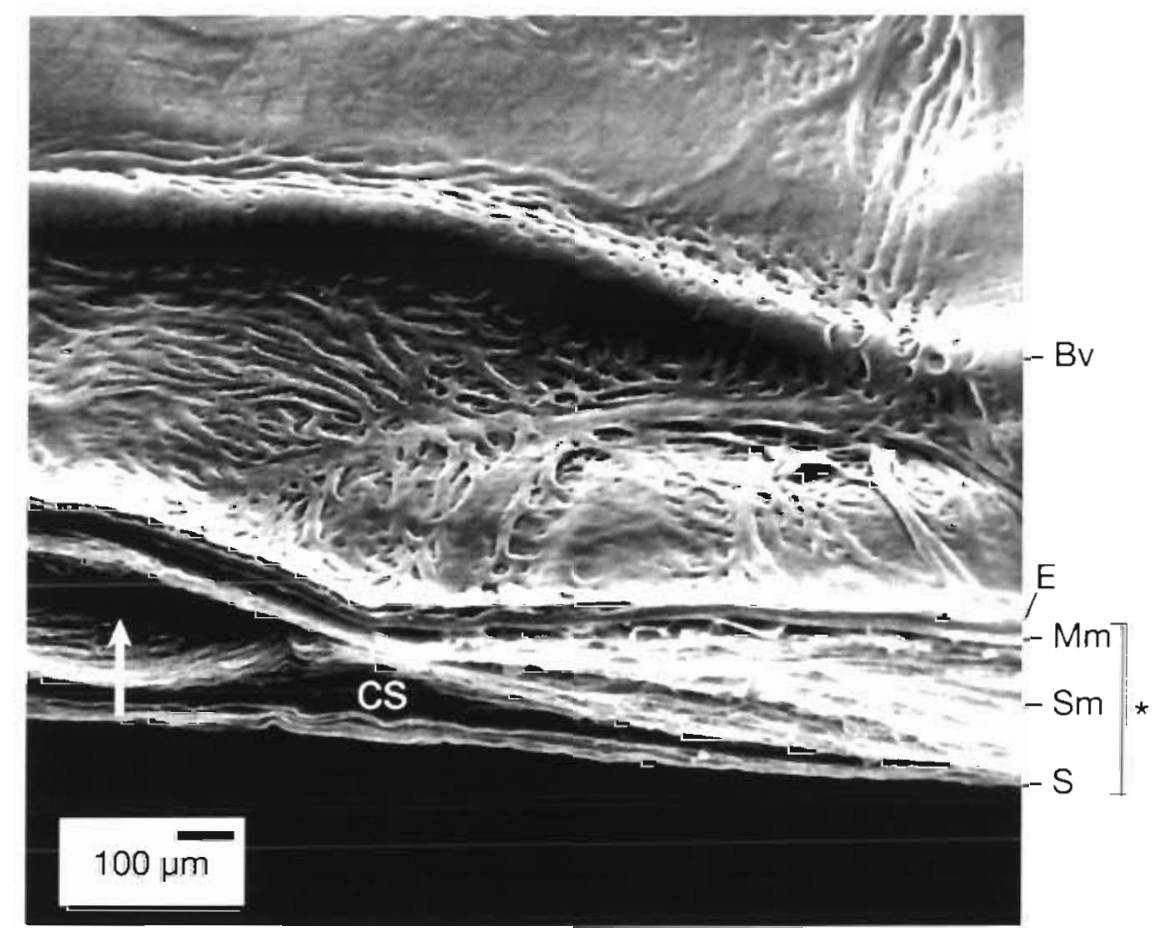

Fig. 1 Anguilla anguilla. Swimbladder wall of an uninfected swimbladder; the smooth surface shows only elevations of the blood vessels. SEM, $50 \times .8 v=$ blood vessel, $* C S=$ cutting surface, $E=$ epithelium, $\mathrm{Mm}=$ muscularis mucosae, $\mathrm{Sm}=$ submucosa. $\mathrm{S}=$ serosa, Arrow = fixation artefact (see text) 
Fig. 2. Anguilla anguilla. Swimbladder wall of an infected, thickened swimbladder. The epithelium is characterised by heavy folds; blood vessels can only be seen at the cutting line. All layers show thickening. SEM, 50 $\times$ * CS = cutting surface, $\mathrm{E}=$ epithelium, $\mathrm{Mm}=$ muscularis mucosae, $\mathrm{Sm}=$ submucosa, $\mathrm{S}=$ serosa

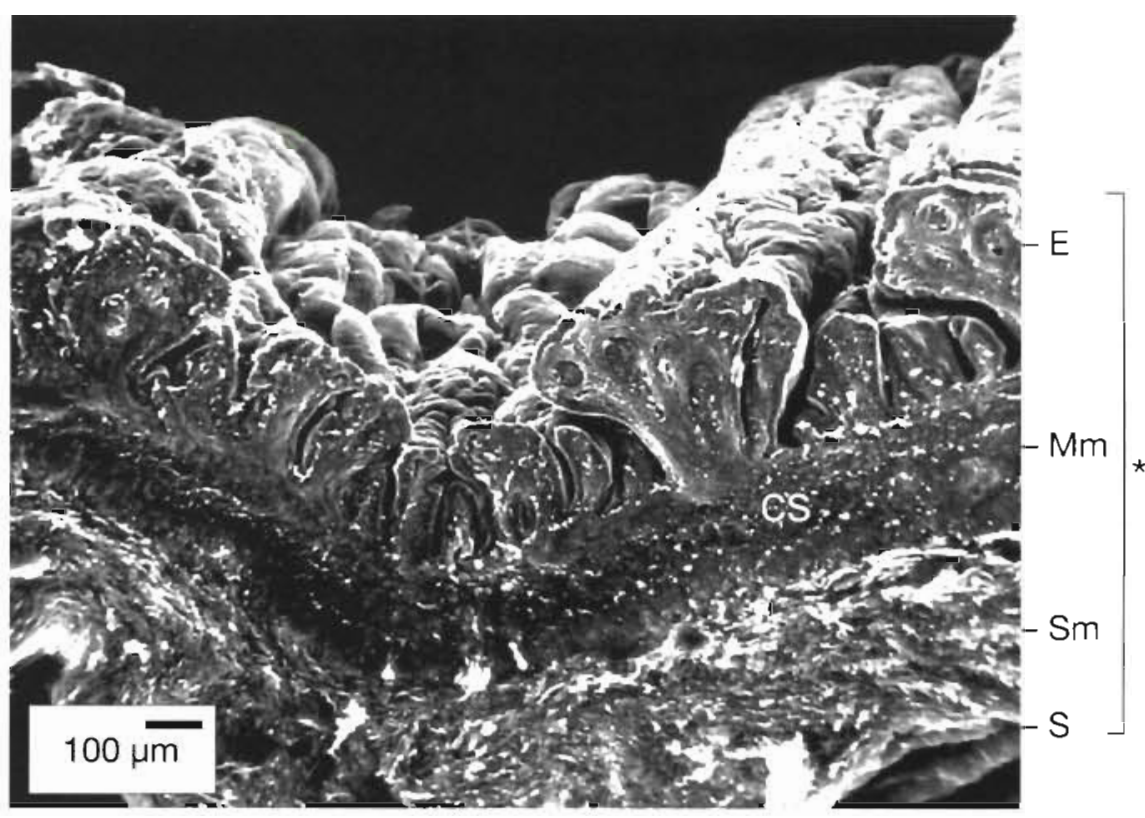

the walls, which sometimes nearly obliterated the lumen of the swimbladder, and severe ultrastructural changes in all layers of the swimbladder wall.

A comparison of a top view on the sections of the uninfected and infected, thickened swimbladder walls clearly shows these alterations, visible in severe cases (Figs. 1 \& 2). Normal swimbladder walls have a smooth surface. Elevations in the surface are usually limited solely to areas with blood vessels (Fig. 1). The tissue layers are arranged strictly parallel to the surface and easily rip apart after fixation of the tissue. Cell borders and the enlargement of the surface by short microvilli become apparent at higher magnifications of the epithelial surface (Fig. 3). Thickened swimbladders, however, are
Fig. 3. Anguilla anguilla. Epithelium of an uninfected swimbladder; higher magnification reveals short microvilli on top of the epithelium and makes cell borders visible. SEM, $2000 x$

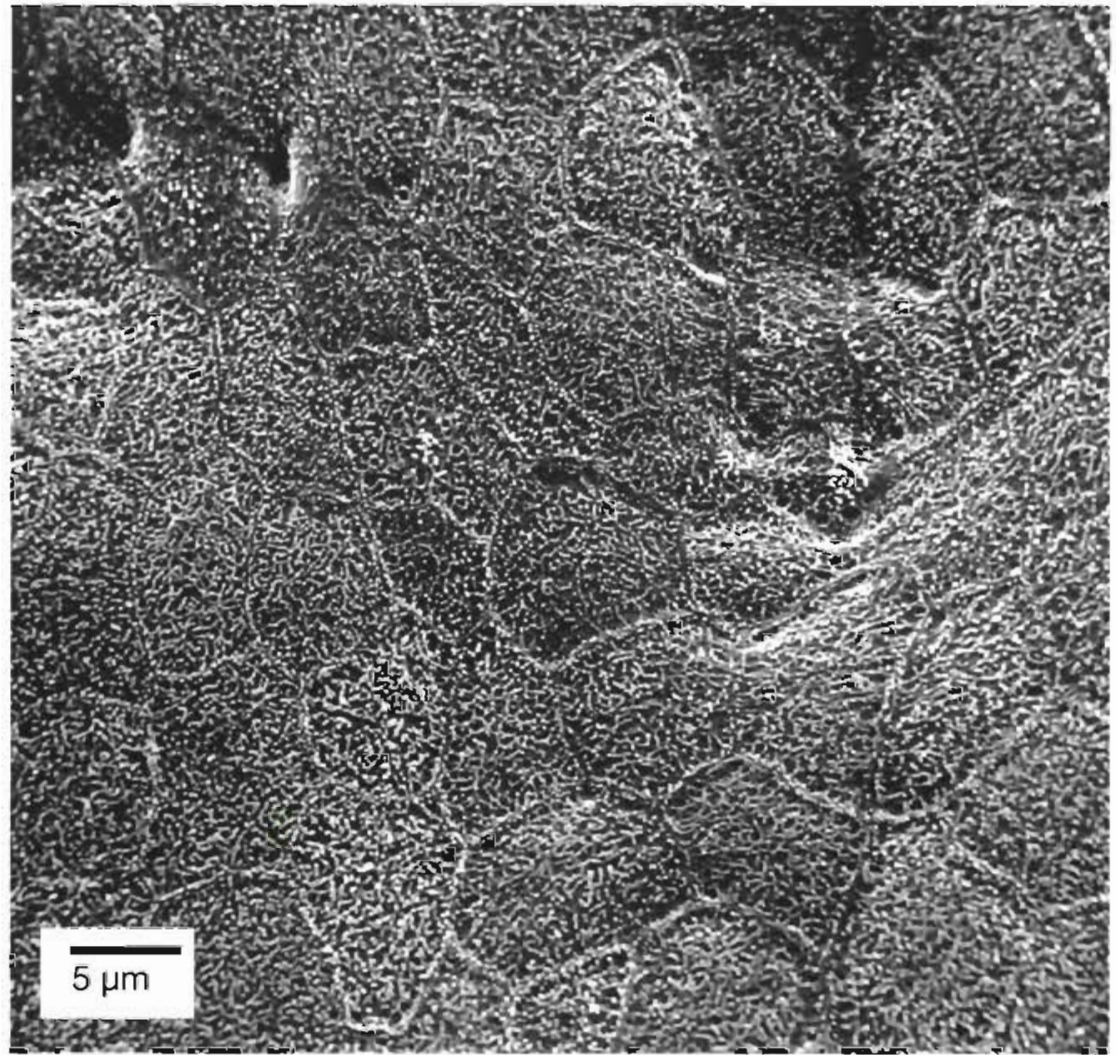




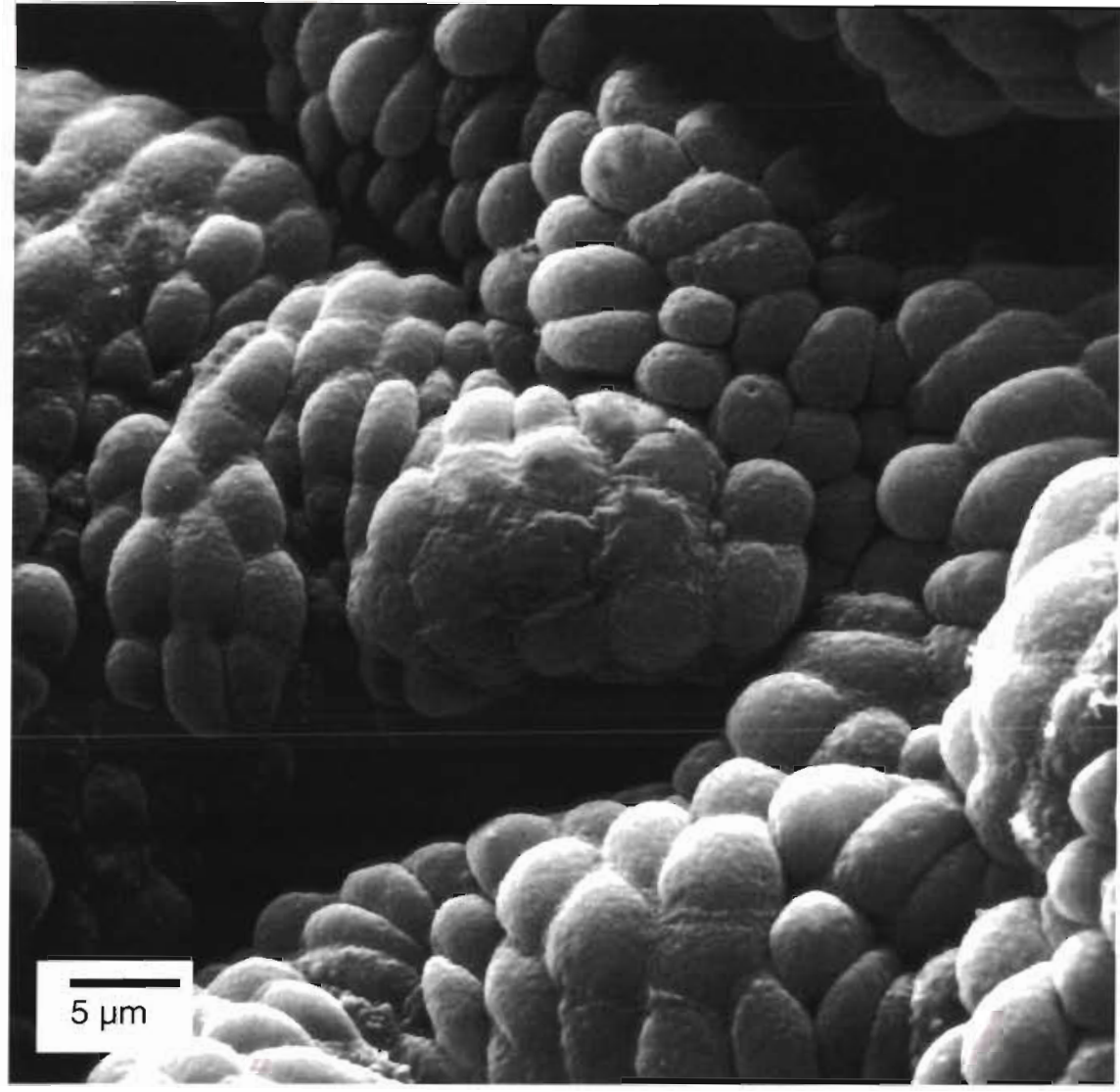

Fig. 4. Anguilla anguilla. Epithelium of an infected swimbladder; in thickened swimbladders the surface shows folds and the cells have a bubbleshaped surface. SEM, 2000x characterised by heavy folds of the epithelium, which itself is much thicker than in uninfected swimbladders (Figs. 2 \& 4). The separate layers of these swimbladder walls have lost their strict order and are meshed together so they do not rip apart after fixation. The surface shows, in addition to the above-mentioned folds, bubble-shaped bulging of the cells, and the microvilli are often reduced or swollen (Fig. 4). Mechanical injuries to the epithelium are rare but can occasionally be seen and were probably caused by the feeding activity of Anguillicola crassus (Fig. 5). The lesion shown is about $30 \mu \mathrm{m}$ in length, which corresponds to the size of the mouth of an adult A. crassus (Taraschewski et al. 1987). Examination of the exudate found in many infected swimbladders and very rarely in uninfected swimbladders revealed no bacterial or fungal infection in the eels. This exudate consists of more or less digested erythrocytes, probably derived from the guts of disrupted adult $A$. crassus and from feeding sites, as well as numerous eggs of $A$. crassus containing second stage larvae (see Würtz 1997).

\section{Transmission electron microscopy}

The ultrastructure of uninfected swimbladders is shown in Figs. 6 to 9. The cells of the epithelium are cubic and attached to each other by a well-developed apical junctional complex (Figs. 6 \& 7). Generally, 2 structures are remarkable in the epithelium. These are short microvilli-like structures at the apical surface facing the swimbladder lumen and a well-developed basal labyrinth (Figs. $6 \& 7$ ). The basal labyrinth is characterised by deep basal membrane folds and is extended to the greatest degree in areas around the blood vessels (Figs. 6 \& 7). The basal part of the epithelium is marked by a basal lamina. Between the epithelium and blood vessels a thin lamina propria with sparse collagen fibres can be seen (Fig. 8). The muscularis mucosae consists of smooth muscle cells which form a dense net and collagen fibres between the different layers of the muscle cells. Additionally, single fibroblasts are situated in the muscularis mucosae. The submucosa of uninfected swimbladders is characterised by fibroblasts and collagen fibres with a mainly longitudinal and transverse orientation (Fig. 9). The individual fibroblasts are surrounded by an extracellular matrix.

Infections with Anguillicola crassus cause changes in the structure of the entire swimbladder. In less severe cases only dilation of the blood vessels and a slight increase in connective tissue can be observed. In more severe cases dramatic changes take place in most of 
Fig. 5. Anguilla anguilla. Epithelium of an infected swimbladder; the arrows mark mechanical injuries to the epithelium with erythrocytes ( $E$ ) issuing from the lesion. In the upper right-hand corner the beginning of the bubble-shaped surface of the cells can be seen. SEM, 2000x

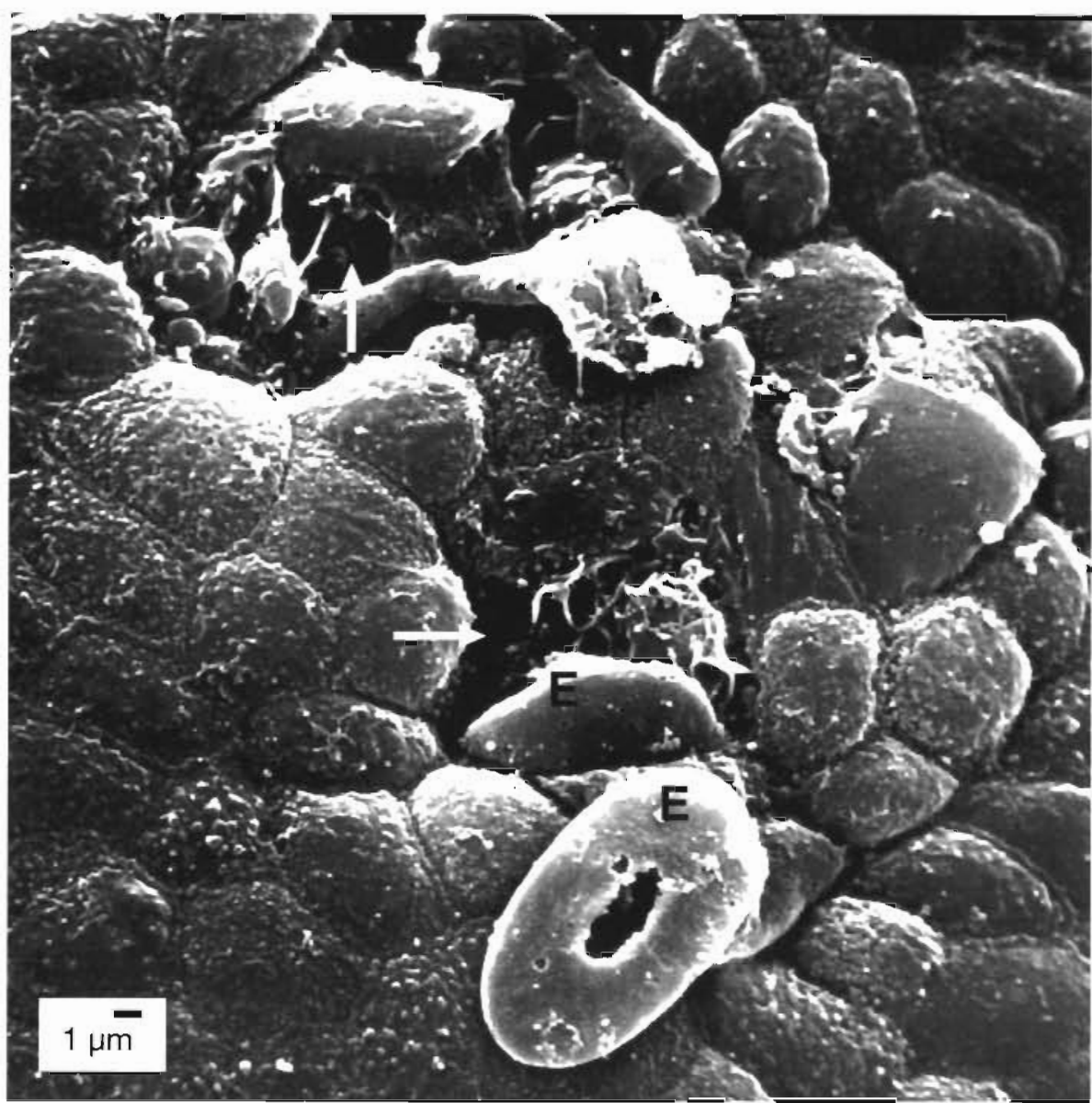

L

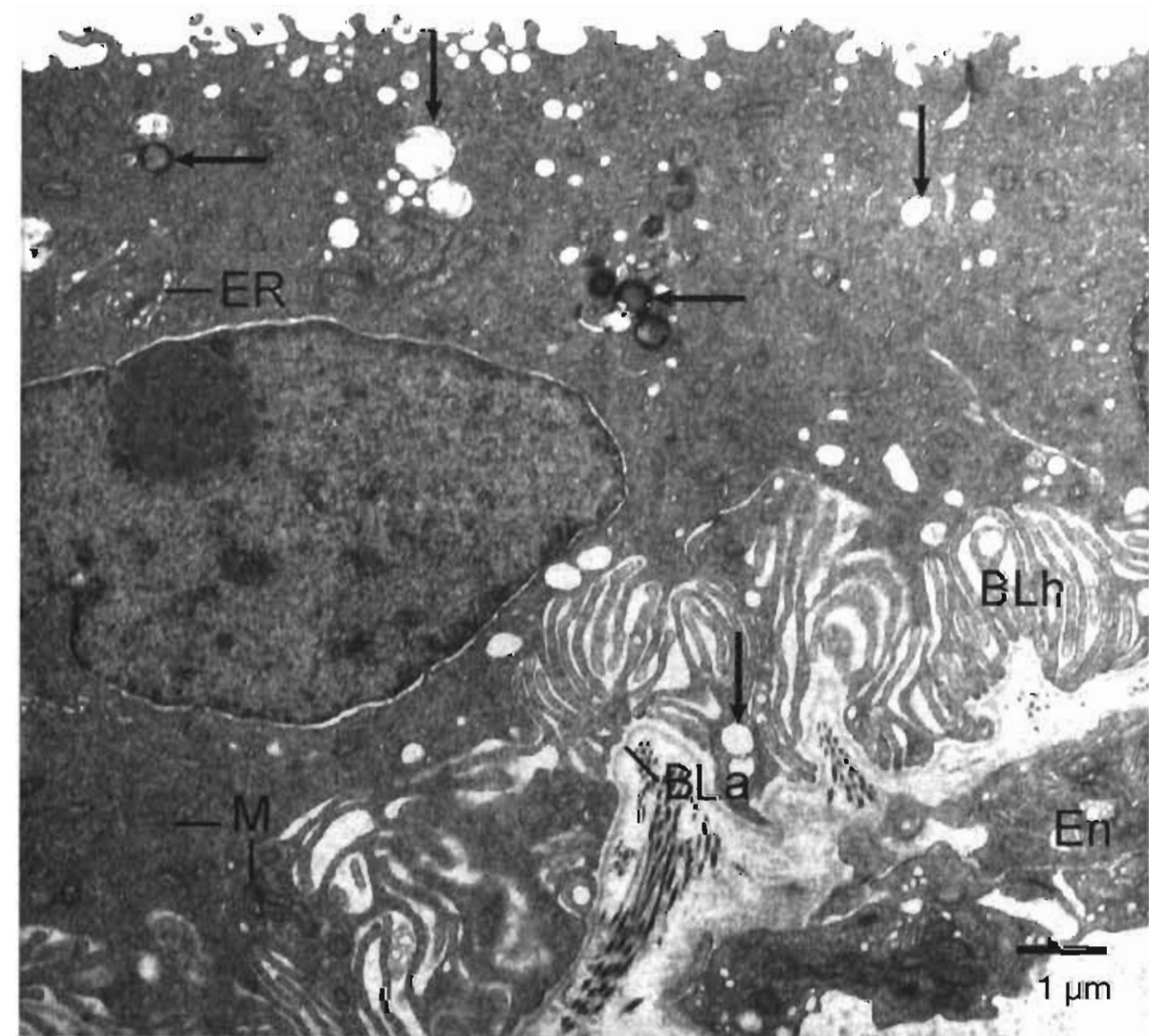

Fig. 6. Anguilla anguilla. Epithelial cell of an uninfected swimbladder; the gas gland cells are cubic, contain different kinds of vesicles and show a well-developed basal labyrinth. Between the basal labyrinth and the lamina propria a thin basal lamina can be seen. TEM, 7000x. BLa = basal lamina, $B L h=$ basal labyrinth, En = endothelial cell, ER = endoplasmic reticulum, $L=$ swimbladder lumen, $\mathrm{M}=$ mitochondria, horizontal arrows = lysosomes, vertical arrows $=$ electron-lucent vesicles 


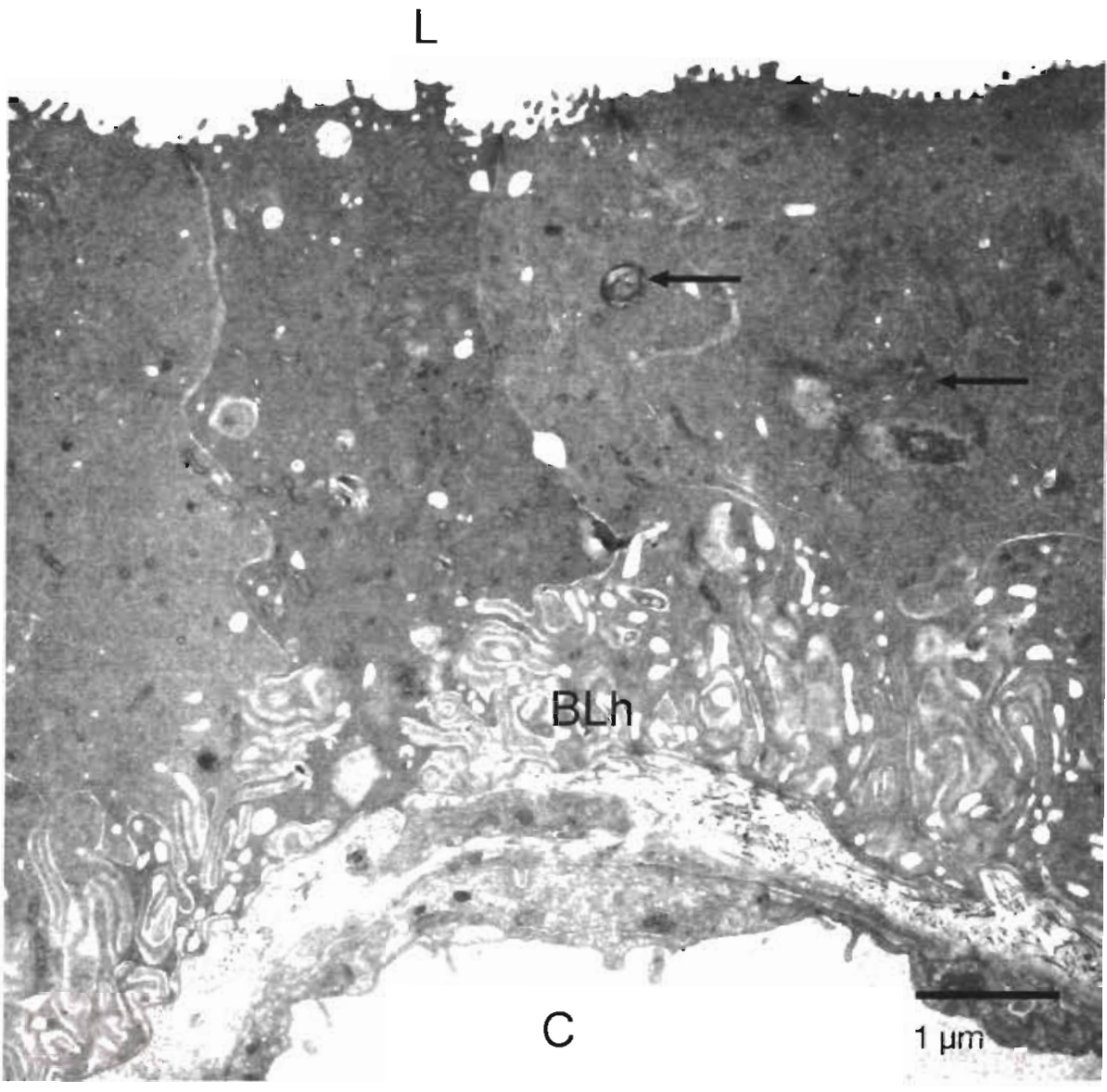

Fig. 7. Anguilla anguilla. Epithelium of an uninfected swimbladder; the basal labyrinth is extended the most around the blood vessels. TEM, $4400 \times$ BLh = basal labyrinth, $\mathrm{C}=$ capil lary, $\mathrm{L}=$ swimbladder lumen, arrows $=$ lysosomes the swimbladder wall layers. Probably the beginning of the deleterious processes in the epithelium is a hypertrophy of epithelial cells accompanied by a change in the shape of the nuclei (Fig. 10). In addition. macrophages and other leukocytes are visible in the lamina propria. This stage is followed by strong proliferative processes leading to epithelial hyperplasia or dysplasia. As a result pseudo-stratified epithelial folds with spherical (Figs. 11 \& 12) or columnar (Fig. 10) cells become visible. The spherical surface of the cells facing the lumen of the swimbladder explain the bubbleshaped surface seen with the scanning electron microscope (Fig. 4). Within these cells many electron-lucent vesicles can be seen. In areas where the folds have contact with each other, there are adhesions between the cells (Figs. $11 \& 12$ ). A well-developed junctional complex can only be seen in the most apical layer of the folds. Deeper-lying cells do not show a strict polarity. Most of the cells within the folds no longer have any contact with the blood vessels. The spherical cells also lack a basal labyrinth and even the cells around blood vessels show reductions in the basal labyrinth. In infected, thickened swimbladders the microvilli are often reduced or swollen. Additionally, the basal lam- ina is thicker (see. Fig. 15). The nuclei in these cells show identations and a different distribution of heterochromatine compared to the usually oval nuclei with a distinct nucleolus in cells of uninfected swimbladders. The lamina propria of many infected swimbladders shows an increase in collagen fibres (Fig. 13). Additionally, the number of macrophages, leukocytes and fibroblasts increase within the lamina propria.

In thickened swimbladders the order of the smooth muscle cells of the muscularis mucosae was to a large extent lost, and a strong increase in fibroblasts and collagen fibres could be observed. The submucosa is affected in the much thicker swimbladder walls and in the presence of numerous third and fourth stage larvae of Anguillicola crassus. In heavily thickened swimbladders a strong fibrosis can be observed (Fig. 14). Collagen fibres are often arranged in bundles without a distinct order. Additionally, the number of fibroblasts and leukocytes, such as macrophages, increases. An overview, showing most of the ultrastructural changes, is provided in Fig. 15.

$\mathrm{L}_{3}$ and $\mathrm{L}_{4}$ larvae of Anguillicola crassus are usually situated in the submucosa. However, in heavily infected eels, larval stages carn be found migrating 
through the different layers of the swimbladder (Molnár et al. 1995). In the area surrounding $A$. crassus larvae, cell debris is regularly seen (Fig. 16). In some cases larvae are surrounded by granulation tissue consisting of leukocytes, macrophages, fibroblasts, proliferating blood vessels and fibrotic parts. Bleeding can often also be observed. Collagen fibres were always detected in the gut of $\mathrm{L}_{3}$ and $\mathrm{L}_{4}$ larvae in the submucosa and sometimes fragments of cells but no host erythrocytes.

\section{DISCUSSION}

The swimbladder of eels infected with Anguillicola crassus undergoes several changes in its structure depending on the time and grade of infection. Some of the changes, such as thickening and clouding of the walls, are obvious macroscopically. Other alterations such as degenerative, inflammatory and proliferative processes are revealed by light microscopy (Van Banning \& Haenen 1990, Molnár et al. 1993, Hartmann 1994, Molnár 1994, Haenen 1995, Molnár et al. 1995). Alterations can be found in all layers of the swimbladder. Many of these alterations can be classified as inflammatory reactions. Inflammations are characterised by dilation of the blood vessels, an increase in endothel permeability, leakage of blood into the tissue and active movement of macrophages, granulocytes and fibroblasts into the tissue as well as fibrotic processes (Roberts 1989, Eder \& Gedigk 1990, Keller 1994). Most of the signs for either acute or chronic inflammations have been observed during the present study and our results correspond to the findings of other authors (Van Banning \& Haenen 1990, Molnár et al. 1993, 1995). Experimentally infected eels showed signs mainly of acute inflammations whereas in the feral eels investigated symptoms of acute and chronic inflammation were detected alongside each other. In addıtion to inflammatory reactions, other pathological changes in the swimbladder wall were found in the present study. Due to the proliferation of epithelial cells, the tissue becomes hyperplastic. Furthermore, alterations in the shape and the structure of the cells as well as changes in the distribution of the chromatin and the form of the nuclei are signs of dysplasia (Eder \& Gedigk 1990). Inflammatory, hyperplastic and dysplastic processes

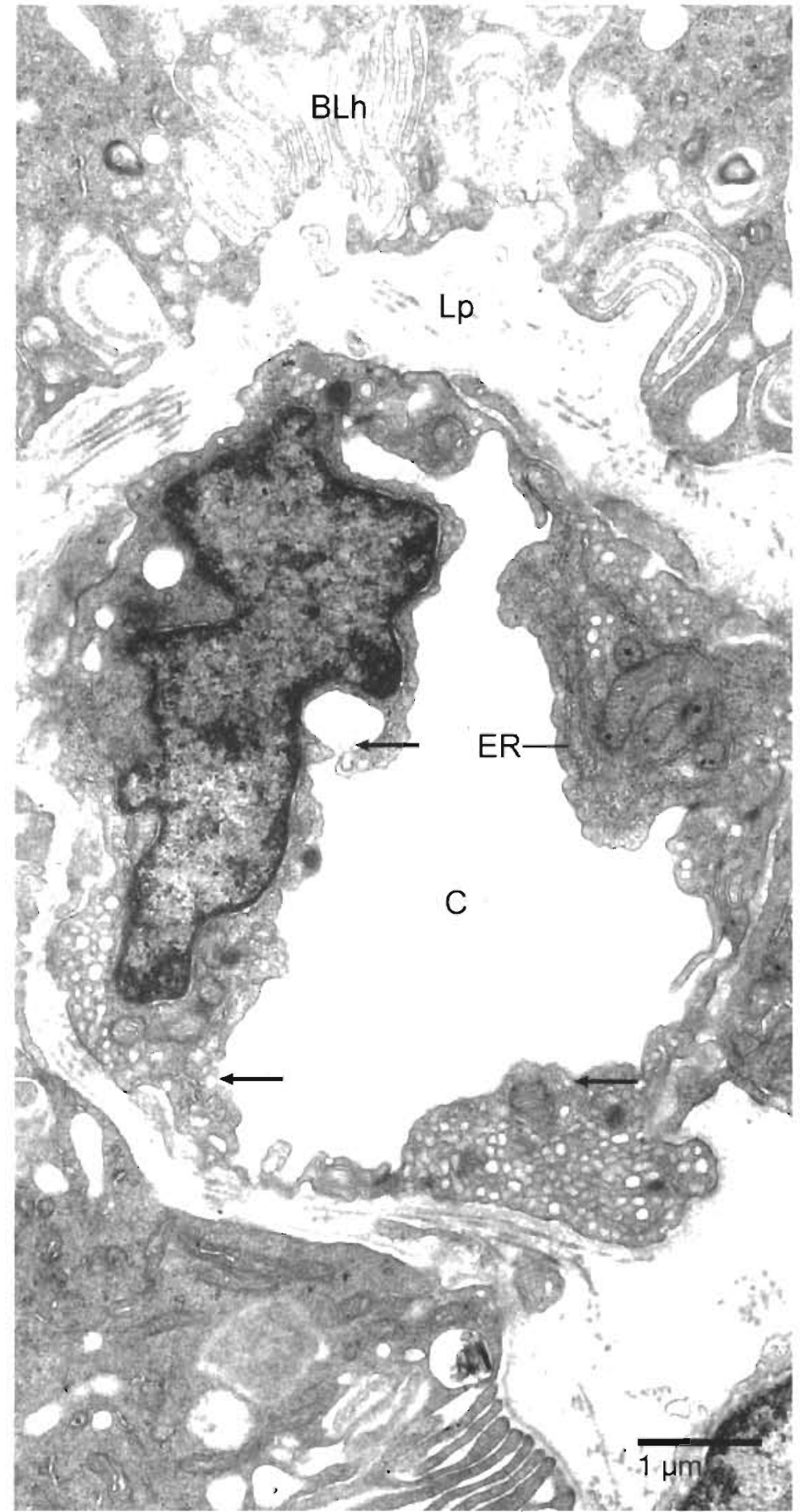

Fig 8 Anguilla angulla. Capllary of an uninfected swimbladder The lamina propna contains sparse collagen fibres. within the endothehum many vesicles indicate high pinocytic actıvity TEM, $12000 \times \mathrm{BLh}=$ basal labyrinth, $\mathrm{C}=$ capillary, $\mathrm{Lp}=$ lamma propra, $\mathrm{ER}=$ endoplasmic reticulum, arrows $=$ pinocytic vesicle

In vanous tissues of fishes infected with different helminth parasites are well known. The inflammatory reactions described above are also found in fish tissue infected with acanthocephalans (Taraschewskı 1988, 
Fig. 9. Anguilla anguilla. Submucosa of an uninfected swimbladder; the submucosa contains mainly collagen fibres and fibroblasts with long extensions. An extracellular matrix is distributed around the fibroblasts. TEM, $3000 \times, C=$ collagen fibres arrows $=$ fibroblasts

Fig. 10. Anguilla anguilla. Hyperplastic epithelium and lamina propria of an infected swimbladder; the cells in thickened swimbladders become columnar and the shape of the nuclei changes. Within the lamina propria numerous leucocytes become visible and the basal labyrinth of the gas gland cells is reduced. TEM, 1100x. $\mathrm{L}=$ lumen, $\mathrm{C}=$ capillary, $\mathrm{M}=$ macrophage, arrow $=$ nuclei with alterations in shape and heterochromatine distribution

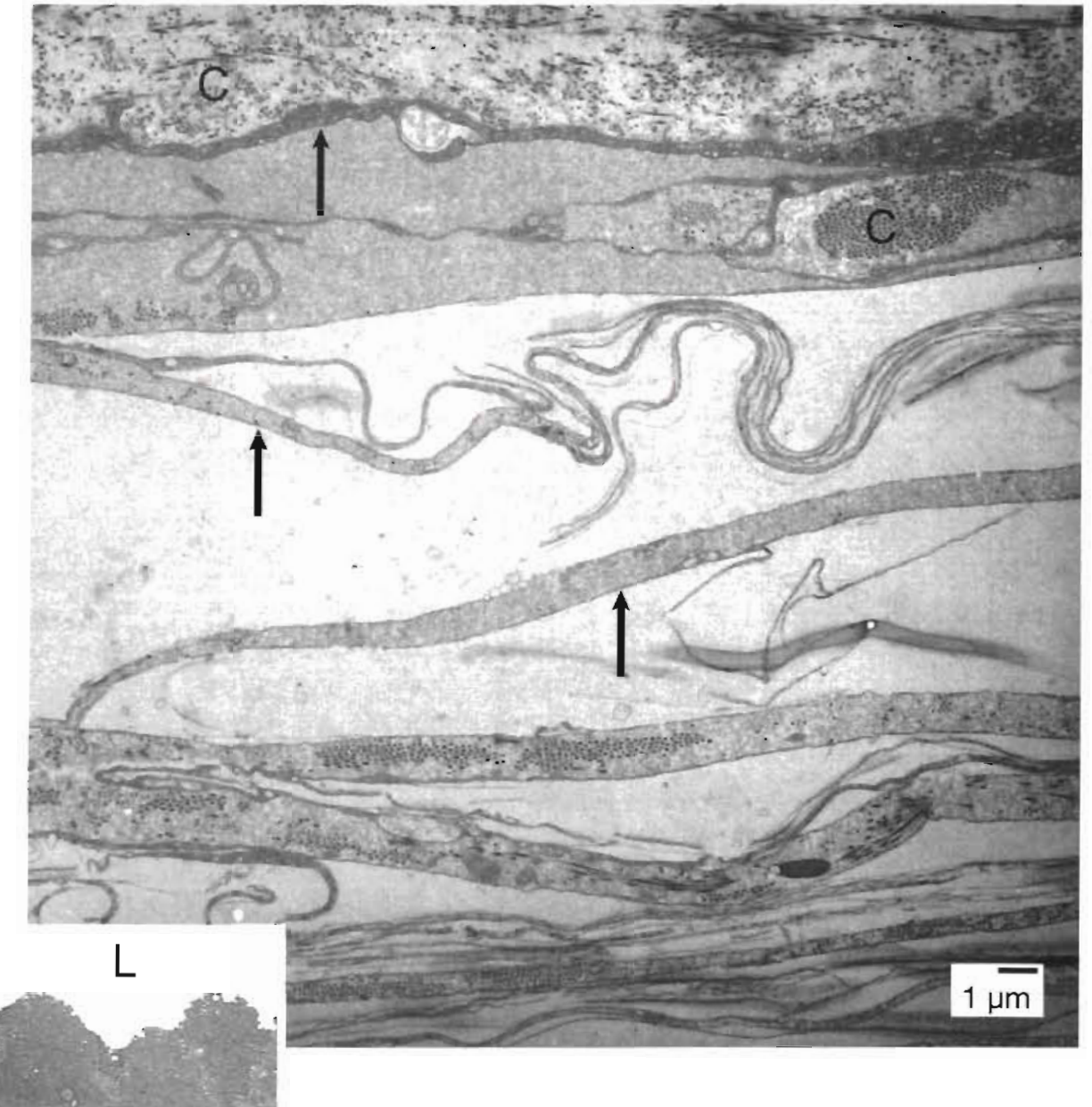

Taraschewski $1989 \mathrm{a}, \mathrm{b}$. In swimbladders of salmonids infected with the nematode Cystidicola sp. lesions of the epithelium, inflammatory reactions and hyperplasia have also been reported (Lankester \& Smith 1980, Ocvirk et al. 1980, Willers et al. 1991, Williams \& Jones 1994). These alterations in the swimbladder tissue of salmonids were interpreted as being the results of numerous mechanical injuries of the epithelium due to the parasites (Black 1984). In other cases secondary infections, mainly fungal infections, are considered responsible for the inflammations of the swimbladder in salmonids infected with $C$. farionis (Ocvirk et al. 1980). However, in the present study no fungal or bacterial swimbladder infections in eels were observed. The alterations in swimbladder tissue are therefore considered to be predominantly due to the presence of A. crassus. Thickening of the wall of hollow sackshaped organs parasitized by helminths seems to be a common phenomenon as also shown from acanthocephalan infections in the lumen of ceca of fishes (De Buron \& Nickol 1994). On the other hand, alterations such as hyperplasia or dysplasia of the swimbladder tissue could also be caused by chemical agents. In $G$ asterosteus aculeatus dysplasia of the swimbladder 
Fig. 11. Anguilla anguilla. Hyperplastic epithelium of an infected, heavily thickened swimbladder; the epithelial cells form folds and tend to become spherical. Most of the cells are not in contact with blood vessels. TEM, 1100x. C = capillary, $\mathrm{L}=$ lumen, arrows $=$ adhesions between epithelial cells

Fig. 12. Anguilla anguilla. Hyperplastic epithelium of an infected, heavily thickened swimbladder. Magnification of Fig. 11; the proliferating cells within the epithelial folds show pseudopodial adhesions and polymorphic nuclei with changes in the distribution of heterochromatin. TEM, 3000x. BLh = basal labyrinth, $F$ = fibroblast, vertical arrows $=$ adhesions between epithelial cells, horizontal arrows = nuclei with alterations in shape and heterochromatine distribution
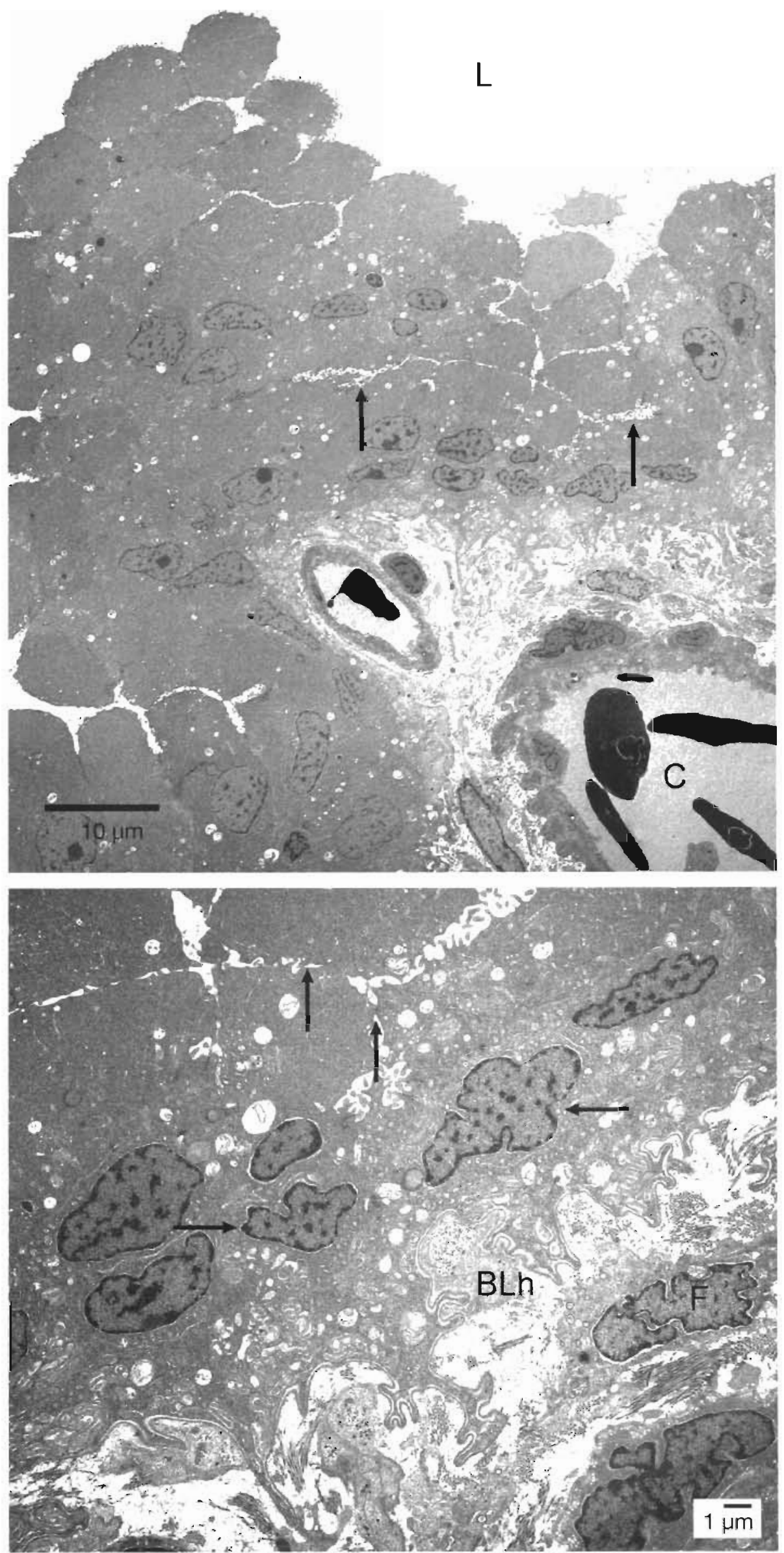

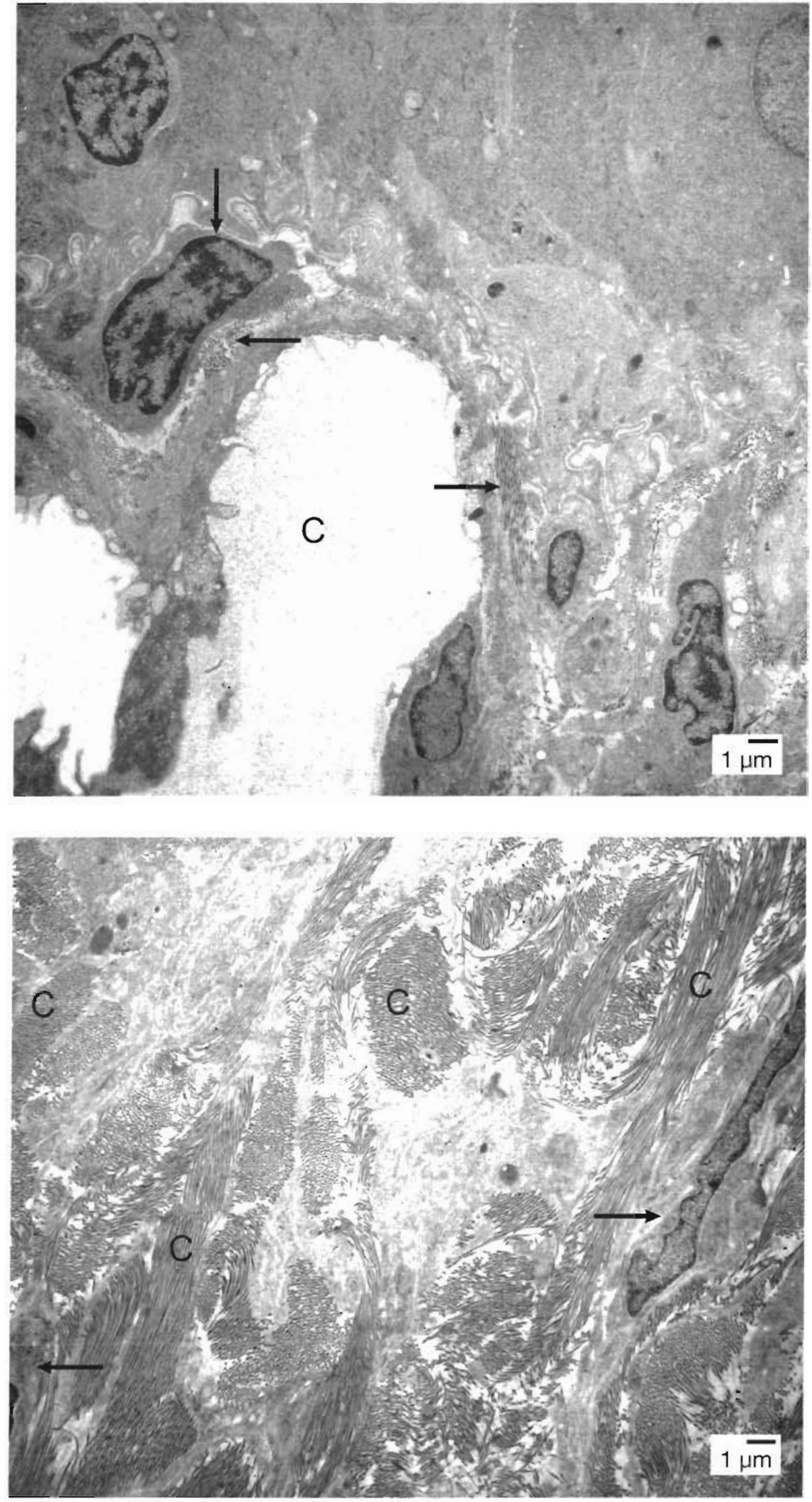

Fig. 13. Anguilla anguilla. Hyperplastic epithelium of an infected, heavily thickened swimbladder; within the lamina propria fibrotic processes can be observed. TEM, $3000 \times . \quad \mathrm{C}=$ capillary, vertical arrow = macrophage, horizontal arrows $=$ collagen fibres

Fig. 14. Anguilla anguilla. Fibrotic submucosa of an infected, heavily thickened swimbladder; the submucosa of heavily thickened swimbladders is characterised by large bundles of collagen fibres with different orientation. TEM, $3000 \times . C=$ bundles of collagen fibres, arrows $=$ fibroblasts 
(A)

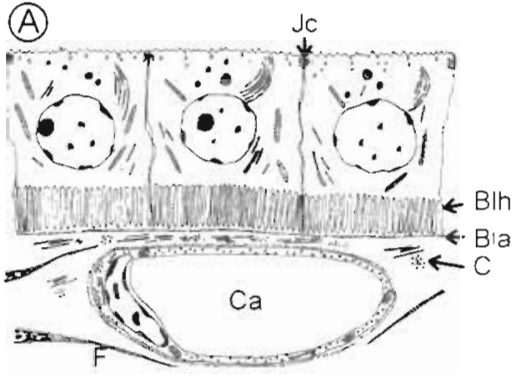

Fig. 15. Anguilla anguilla. Schematic drawing of the epithelium and the lamina propnd (A) Uninfected swimbladder. Gas gland cells are cubic, show a conspicuous basal labyrinth and short microvilli and are marked by a thin basal lamina. The gas gland cells are followed by a thin lamina propria contanıng small numbers of collagen fibres and tibroblasts. (B) Infected, slightly thickened swimbladder Gas gland cells in slightly thickened swimbladder walls show a reduction of the basal labyrunth and a change in shape A tendency toward loose polarity is visible. The basal lamina becomes slightly thicker as does the lamina propria, in which the number of collagen fibres and fibroblasts increases. (C) Infected, heavily thickened swimbladder. The prolifelation of gas gland cells leads to a pseudostratified tissue in which the cells have lost therr polanty The basal labyrinth is further reduced but lateral membranes form similar folds Macrophages are visible in this hyperplastic tissue. Additionally, the basal lamina increases in thickness and the lamina propria becomes heavily fibrotıc Blh = basal labyrınth, Bla = basal lamina, $\mathrm{C}=$ collagen fibres, $\mathrm{Ca}=$ capillary, $\mathrm{F}=$ fibroblast, $\mathrm{Jc}=$ junctional complex, $\mathrm{M}=$ macrophage

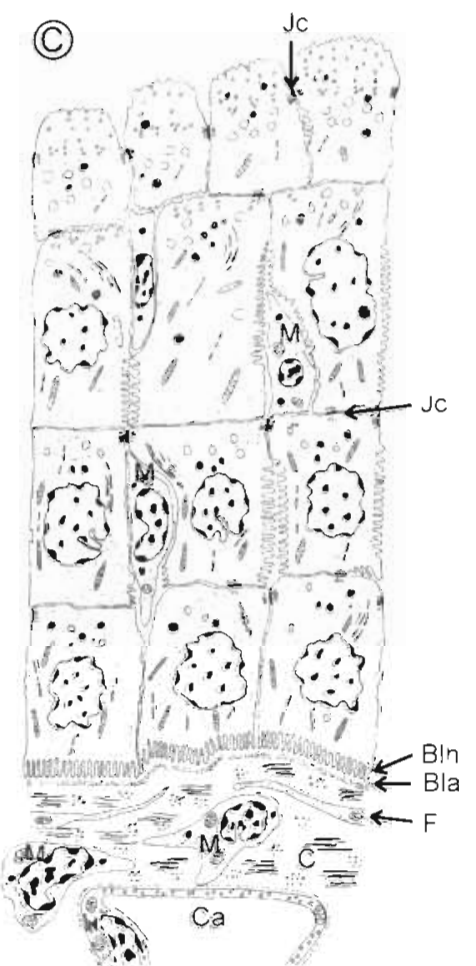

Fig. 16. Anguilla anguilla. Submucosa of an infected swimblad. der, containing a larva; the larva's surroundings are characterised by cell debris from the necrotic submucosa. This situation is restricted to the area where larvae move. TEM, $3000 \times$ $\mathrm{L}_{4}=$ larvae (fourth stage), $\mathrm{N}=$ nuclei of destroyed cells, arrows $=$ inflated mitochondria

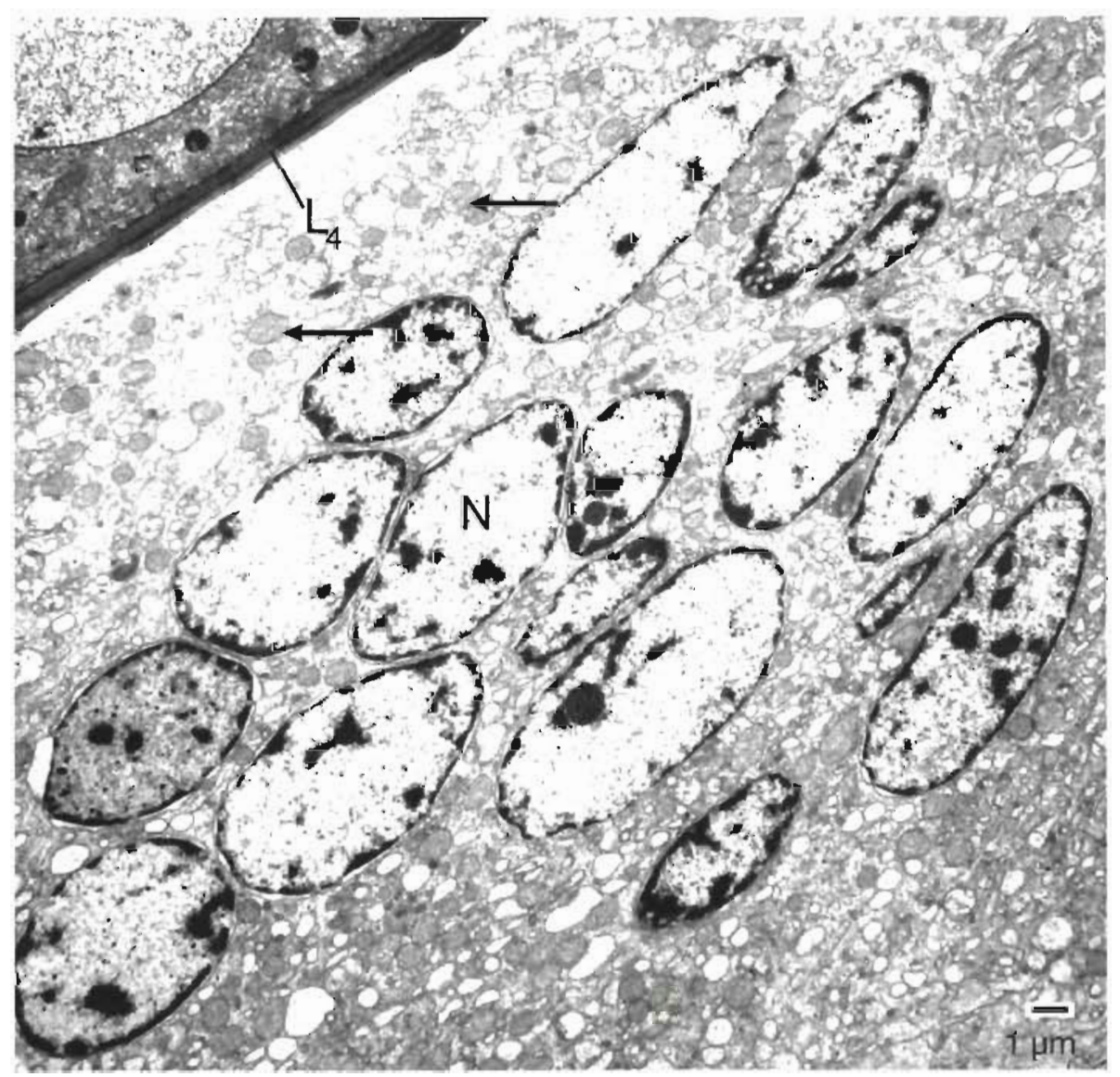


tissue was observed after exposure of the fish to industrial softener (Hofer \& Lackner 1995). Helminth parasites may excrete various substances in the tissues of their hosts such as proline, which stimulates the host to synthesize collagen and thus leads to the formation of connective tissue near the parasite (see Köhler \& Voigt 1988). Ammonia, which is excreted by many helminths (Köhler \& Voigt 1988), can also lead to hyperplasia, haemorrhagia and necrosis in fish tissue (Amlacher 1992). However, nothing is known yet about the metabolism and excretory products of $A$. crassus. The possibility cannot therefore be excluded that toxic excretory products of $A$. crassus could play a role in the deleterious processes in the swimbladder together with mechanical injuries.

Our histological studies, especially those on experimentally infected eels, showed that a single infection, even with up to 40 larvae, does not necessarily lead to serious alterations in the swimbladder tissue. These findings correspond with results of several authors who reached this conclusion based on examination of naturally infected or farmed eels (Van Banning \& Haenen 1990, Molnár et al. 1993, Haenen 1995). Even continuous infections with up to 20 larvae per week over a period of $20 \mathrm{wk}$ (Knopf unpubl.) did not cause thickenings in the swimbladder walls as severe as those which are observed in naturally infected eels. Obviously several infections over a long period of time and co-factors prevailing only in the field are needed to cause heavy thickening of the swimbladder tissues. However, examinations of the gas content in swimbladders show that single infections can lead to malfunctions of gas secretion in the swimbladder (Würtz et al. 1996). This functional disorder could be attributed to the beginning dysplasia of the epithelium due to mechanical injuries or toxic excretion products which could disturb the physiology of the gas gland cells. Probably physiological changes in the gas gland cells take place before histological changes can be detected; it therefore seems that the gas deposition in the swimbladder is a quicker and more sensitive indicator of a disturbed functioning of this organ than histological alterations. However, thickened swimbladder walls of naturally infected eels were associated with more pronounced decreases in oxygen content inside the bladder than swimbladder walls in eels which were infected experimentally. In thickened swimbladders histological alterations which probably hinder gas deposition can be observed. In severe cases many of the hyperplastic cells are not connected to the blood vessels. Therefore, the diffusion or transport distances from cells to the blood vessels increase. For gas secretion it is essential that acidic metabolites can reach the blood vessels (Pelster \& Scheid 1993, Würtz et al. 1996) and factors hindering this process would disturb gas secretion. Another factor hindering the diffusion or transport probably is the reduction of the basal labyrinth and the lost polarity of the gas gland cells. Recent studies give evidence for the presence of a membrane-bound carbonic anhydrase in the basal labyrinth of gas gland cells in the European eel (Würtz et al. 1999). The activity of carbonic anhydrase was found to be essential for acid transfer to the blood (Pelster 1995). A reduction of the basal labyrinth or problems in the development of the cells' polarity probably will lower the activity of this enzyme. The thickened basal lamina and the fibrotic processes in the lamina propria certainly hinder the diffusion of acidic metabolites into the blood vessels. Additionally, it is known that fibrotic tissue is characterised by loss of elasticity (Eder \& Gedigk 1990). Gas secretion is presumably controlled by tension receptors (Tytler \& Blaxter 1973). A loss in elasticity in thickened swimbladders can thus lead to malfunction of this organ. Probably there are some factors acting together which result in the loss of function of swimbladders infected with Anguillicola crassus.

Concerning the feeding behaviour of larval Anguillicola crassus, the assumption of Polzer \& Taraschewski (1993) that larvae do not feed on blood was confirmed in the present study. In contrast to adults, larvae did not have erythrocytes in their guts. A cellular host reaction consisting of plasma cells, granulocytes and macrophages attacking the migrating $\mathrm{L}_{3}$ and $\mathrm{L}_{4}$ was not found in this study (see also Molnár et al. 1993). In fact, the granulocytes and macrophages regularly observed in areas with larvae probably only remove the cell debris created by the worms. The $\mathrm{L}_{3}$ and $\mathrm{L}_{4}$ larvae inside the swimbladder wall seem to be immunologically camouflaged (likely by features related to their epicuticle, see Blaxter et al. 1992) although they possess a trypsin-like proteinase which is probably discharged from their mouth opening (Polzer \& Taraschewski 1993).

As documented in this study, the swimbladder wall of the European eel heavily and continuously infected by Anguillicola crassus develops conspicuous alterations. Unfortunately, we do not know whether this also occurs in the natural host, the Japanese eel Anguilla japonica. But as reported by Egusa (1979) Japanese eels do not become as frequently and intensively infected by $A$. crassus as European eels and it appears as if, thus, the swimbladder wall in these eels is less affected by the parasite than in the eels described in this paper. Therefore, the different pathogenicity displayed in the 2 eels species seems to result from different ecological factors prevailing in the various aquatic biotopes and/or from differences in the immunological response of the 2 congeneric hosts. 
Acknowledgements. We wish to thank Sabine Purper (University of Karlsruhe) for her assistance with electron microscopical and photographical techniques and Cornelia Haug (University of Karlsruhe) for her assistance in embedding the samples. Thanks are due to Willi Salvenmoser for critically reading the paper. We also thank the Angelsportverein Karlsruhe for permission to take eels from the various waters.

\section{LITERATURE CITED}

Amlacher E (1992) Taschenbuch der Fischkrankheiten, 6th edn. Gustav Fischer Verlag, Stuttgart

Belpaire C, De Charleroy D, Thomas K, Van Damme P, Ollevier $F$ (1989) Effects of eel restocking on the distribution of the swimbladder nematode Anguillicola crassus in Flanders, Belgium. J Appl Ichthyol 5:151-153

Black G (1984) Swimbladder lesions in lake trout Salvelinus namaycush associated with mature Cystidicola stigmatura (Nematoda). J Parasitol 70:441-443

Blaxter ML, Page AP, Rudin W, Maizels RM (1992) Nematode surface coats: actively evading immunity. Parasitol Today $8: 143-147$

Bonneau S, Blanc G, Petter A.J (1991) Etude sur la biologie des premiers stades larvaires d'Anguillicola crassus (Nematoda, Dracunculoidea) spécificité de l'hôte intermédiaire et influence de la température sur la durée du développement. Bull Fr Pêche Piscic 320:1-6

Canestri-Trotti G (1987) Occurrence of the nematode Anguillicola crassa KUWAHARA, NIMI \& ITAGAKI, 1974 in eels from the Po delta, Italy. Bull Eur Assoc Fish Pathol 7 : $109-111$

De Buron J, Nickol BB (1994) Histopathological effects on the acanthocephalan Leptorhynchus thecatus in the ceca of the green sunfish Lepomis cyanellus. Trans Am Microsc Soc 113:161-168

De Charleroy D, Grisez L, Thomas K, Belpaire C, Ollevier F (1990) The life cycle of Anguillicola crassus. Dis Aquat Org 8:77-84

Dekker W, Van Willigen J (1989) Short note on the distribution and abundance of Anguillicola in The Netherlands. J Appl Ichthyol 1:46-47

Dorn E (1961) Über den Feinbau der Schwimmblase von Anguilla vulgaris L. Licht- und Elektronenmikroskopische Untersuchungen. Z Zellforsch 55:849-912

Dupont F, Petter A. (1988) Anguillicola, une épizootie plurispécifique en Europe apparition de Anguillicola crassa (Nematoda, Anguillicolidae) chez l'anguille européenne Anguilla anguilla en Camargue, sud de la France. Bull Eur Assoc Fish Pathol 308:38-41

Eder M, Gedigk P (1990) Allgemeine Pathologie und Pathologische Anatomie, 33rd edn. Springer Verlag, Berlin

Egusa S (1979) Notes on the culture of the European eel (Anguilla anguilla L.) in japanese eel-farming ponds. Rapp P-V Réun Comm Int Explor Sci Mer Médit 174:51-58

Fänge R (1953) The mechanisms of gas transport in the euphysoclist swimbladder. Acta Physiol Scand 30:1-133

Fontaine YA, Le Belle N, Lopez E, Querat B, Vidal B, Barthelemy L, Sebert P, Alinat J, Petter AJ (1990) Infestation de populations françaises d'anguilles (Anguilla anguilla L.) par des nematodes (Anguillicola crassus): essais thérapeutiques évaluation de risques potentiels liés a l'ecophysiologie de l'hôte. Ann Parasitol Hum Comp 65 $64-68$

Fries LT, Williams J, Johnson SK (1996) Occurrence of Anguillicola crassus, an exotic parasitic swim bladder nematode of eels, in the southeastern United States. Trans Am Fish
Soc $125 \cdot 794-797$

Haenen OLM (1995) Anguillicola crassus (Nematoda, Dracunculoidea) infections of European eel (Anguilla anguilla) in the Netherlands: epidemiology, pathogenesis and pathobiology. Dissertation, Landbouw Universiteit, Wageningen

Hartmann F (1994) Untersuchungen zur Biologie, Epidemiologie und Schadwirkung von Anguillicola crassus KUWAHARA, NIIMI \& ITAGAKI 1974 (Nematoda), einem blutsaugenden Parasiten in der Schwimmblase des Europäischen Aals (Anguilla anguilla), 1st edn. Shaker Verlag, Aachen

Hofer R, Lackner R (1995) Fischtoxikologie, Theorie und Praxis. Gustav Fischer Verlag, Jena

Höglund J, Andersson J, Wickström H, Reizenstein M (1992) The distribution of Anguillicala in Sweden and its association with thermal discharge areas. Irish Fish Invest Ser A (Freshw) 36:143-150

Keller R (1994) Immunologie und Immunpathologie, 4th edn. Thieme Verlag, Stuttgart

Kennedy CR, Fitch DJ (1990) Colonization, larval survival and epidemiology of the nematode Anguillicola crassus, parasitic in the eel, Anguilla anguilla, in Britain. J Fish Biol 36: $117-131$

Kim YG, Kim EB, Kim JY, Chun SK (1989) Studies on a nematode, Anguillicola crassus parasitic in the air bladder of the eel. J Fish Pathol 2:1-18

Köhler P, Voigt W (1988) Nutrition and metabolism. In: Mehlhorn $\mathrm{H}$ (ed) Parasitology in focus. Springer Verlag, Berlin, p $412-452$

Køie M (1988). Parasites in European eel Anguilla anguilla (L.) from Danish freshwater, brackish and marine localities. Ophelia 29:93-118

Koops H, Hartmann F (1989) Anguillicola-infestations in Germany and in German eel imports. J Appl Ichthyol 1:41-45

Lankester M, Smith J (1980) Host specifity and distribution of the swimbladder nematodes Cystidicola farionis Fischer, 1798 and C. cristivomeri White, 1941 (Habronematoidea), in salmonid fishes of Ontario. Can J Zool 58:1298-1305

Mo TH, Steien SH (1994) First observation of the eel swimbladder nematode Anguillicola crassus in Norway. Bull Eur Assoc Fish Pathol 14:164-164

Möller H, Holst $\mathrm{S}$, Lüchtenberg $\mathrm{H}$, Petersen F (1991) Infection of eel Anguilla anguilla from the river Elbe estuary with two nematodes, Anguillicola crassus and Pseudoterranova decipiens. Dis Aquat Org 11:193-199

Molnár K (1994) Formation of parasitic nodules in the swimbladder and intestinal walls of the eel Anguilla anguilla due to infections with larval stages of Anguillicola crassus. Dis Aquat Org 20:163-170

Molnár K, Baska F, Csaba G, Glávits R, Székely C (1993) Pathological and histopathological studies of the swimbladder of eels Anguilla anguilla infected with Anguillicola crassus (Nematoda: Dracunculoidea). Dis Aquat Org 15:41-50

Molnár K, Szakolczai J, Vetesi F (1995) Histological changes in the swimbladder wall of eels due to abnormal location of adults and second stage larvae of Anguillicola crassus. Acta Vet Hung 43:125-137

Moravec F (1992) Spreading of the nematode Anguillicola crassus (Dracunculoidea) among the eel populations in Europe. Folia Parasitol 39:247-248

Moravec F, Konecny R (1994) Some new data on the intermediate and paratenic hosts of the nematode Anguillicola crassus KUWAHARA, NIIMI \& ITAGAKI, 1974 (Dracunculoidea), a swimbladder parasite of eels. Folia Parasitol 41 : $65-70$ 
Moravec F, Taraschewski H (1988) Revision of the genus Anguillicola YAMAGUTI 1935 (Nematoda: Anguillicolidae) of the swimbladder of eels, including descriptions of two new species, A. novaezelandiaesp. n. and A. papernai sp. n. Folia Parasitol 35:125-146

Moravec F, Di Cave A, Paggi L (1993) Studies on the development of Anguillicola crassus Kuwahara, Niimi \& Itagaki, 1974 (Nematoda: Dracunculoidea) in the intermediate host. Folia Parasitol 40:39-48

Moravec F, Di Cave A, Orecchia P, Paggi L (1994) Experimental observations on the development of Anquillicola crassus (Nematoda: Dracunculoidea) in its definitive host, Anguilla anguilla (Pisces). Folia Parasitol 41:138-148

Nagasawa K, Kim Y, Hirose H (1994) Anguillicola crassus and A. globiceps (Nematoda: Dracunculoidea) parasitic in the swimbladder of eels (Anguilla japonica and A. anguilla) in East Asia: a review. Folia Parasitol 41:127-137

Neumann W (1985) Schwimmblasenparasit Anguillicola bei Aalen. Fischer \& Teichwirt 11:322

Ocvirk J, Snoj N, Brglez J (1980) Discovery of Cystidicola farionis (Fischer) in wild brown trout and the pathoanatomical changes caused by them. Ichthyology 12:27-31

Pelster B (1995) Mechanisms of acid release in isolated gas gland cells of the European eel Anguilla anguilla. Am J Physiol 269:R793-R799

Pelster B, Scheid P (1993) Metabolism of the swimbladder epithelium and the single concentrating effect. Com Biochem Physiol 105A:383-388

Polzer M, Taraschewski H (1993) Identification and characterization of the proteolytic enzymes in the developmental stages of the eel-pathogenic nematode Anguillicola crassus. Parasitol Res 79:24-27

Roberts R (1989) Fish pathology, 2nd edn. Baillière Tindall, London

Schabuss M, Konecny R, Belpaire C, Schiemer F (1997) Endoparasitic helminths of the European eel, Anguilla anguilla, from four disconnected meanders from the rivers Leie and Scheldt in western Flanders, Belgium. Folia Parasitol 44:12-18

Spurr AR (1969) A low-viscosity epoxy resin embedding medium for electron microscopy. J Ultrastruct Res 26: $31-43$

Székely C, Làng M, Csaba G (1991) First occurrence of Anguillicola crassus in Hungary. Bull Eur Assoc Fish Pathol 11:162

Taraschewski $H$ (1988) Host-parasite interface of fish acanthocephalans. I. Acânthocephalus anguillae (Palaeacan-

Editorial responsibility: Wolfgang Körting

Hannover, Germany thocephala) in naturally infected fishes: LM and TEM investigations. Dis Aquat Org 4:109-119

Taraschewski H (1989a) Host-parasite interface of Neoechinorhynchus rutili (Eoacanthocephala) in naturally infected salmonids. J Fish Dis 12:39-48

Taraschewski $\mathrm{H}$ (1989b) Acanthocephalus anguillae in intraand extraintestinal positions in experimentally infected juveniles of goldfish and carp and in sticklebacks. J Parasitol 75:108-118

Taraschewski H, Moravec F, Lamah T, Anders K (1987) Distribution and morphology of two helminths recently introduced into European eel populations: Anguillicola crassus (Nematoda, Dracunculoidea) and Paratenuisentis ambiguus (Acanthocephala, Tenuisentidae). Dis Aquat Org 3: $167-176$

Thomas K, Ollevier F (1993) Hatching, survival, activity and penetration efficiency of second-stage larvae of Anguillicola crassus (Nematoda). Parasitology 107:211-217

Tytler P, Blaxter J (1973) Adaptation by cod and saithe to pressure changes. Neth J Sea Res 7:31-45

Van Banning P, Haenen OLM (1990) Effects of the swimbladder nematode Anguillicola crassus in wild and farmed eel, Anguilla anguilla. In: Perkins FO, Cheng TC (eds) Pathology in marine science. Proc 3rd Int Coll on Path in Marine Aquaculture, Gloucester Point, Virginia. Academic Press Inc, New York, p 317-330

Willers W, Dubielzig R, Miller L (1991) Histopathology of the swimbladder of the Cisco due to the presence of the nematode Cystidicola farionis Fischer. J Aquat Anim Health 3: $130-133$

Williams H, Jones A (1994) Parasitic worms of fish. Tylor \& Francis, London

Würtz J (1997) Untersuchungen zur Pathogenität des Schwimmblasen-Nematoden Anguillicola crassus im Labor und Freiland. Verlag Mainz, Aachen

Würtz J, Taraschewski H, Pelster B (1996) Changes in gas composition in the swimbladder of the European eel (Anguilla anguilla) infected with Anguillicola crassus. Parasitol 112:233-238

Würtz J, Knopf K, Taraschewski H (1998) Distribution and prevalence of Anguillicola crassus (Nematoda) in eels (Anguilla anguilla) of the rivers Rhine and Naab. Germany. Dis Aquat Org 32:137-143

Würtz J, Salvenmoser W, Pelster B (1999) Localisation of carbonic anhydrase in swimbladder of European eel (Anguilla anguilla) and perch (Perca fluviatilis). Acta Physiol Scand (in press)

Submitted: August 10, 1998; Accepted: December 12, 1998 Proofs received from author(s): December 16, 1999 